\title{
Exploitative Learning and Entrepreneurial Opportunity Recognition of a Family Business in Hong Kong during and after the Second World War
}

Cherry Cheung, London South Bank University

\begin{abstract}
This study examines the role of exploitative learning in entrepreneurial opportunity recognition at the time of war and peace. Utilising some unique, qualitative, longitudinal oral history interviews collected from informants from a family business, our qualitative finding indicates that, at the time of war and conflict, risk and physical immobility restricted exploitation within a narrowly confined geographical and knowledge contexts. Our case illustrates that success under such condition is largely determined by whether one can efficiently exploit their existing capabilities under contextual and circumstantial constraints, and to reconfigure their capabilities utilising local knowledge and resources. When peace returns, our findings indicate whilst there is no obvious external barrier for radical exploration, exploitation success during war and conflict may result in competency trap, undermining an organisation's transformation after war and conflict.
\end{abstract}

\section{Keywords}

Family business, war, conflict, exploitation learning, exploitation trap

\section{Introduction}


Studies have long suggested that a balance between exploitation and exploration is essential for successful product development (Sheremata, 2000; Iansiti and Clark, 1994) and long term performance (March, 1991; Boisot and Child, 1999). Despite this, however, exploitative learning is often seen as the 'ugly', 'less glamourous' sister of explorative learning. It is mostly involved directed search emphasizing limiting variety and building closely on the existing knowledge base (McGrath, 2001). Explorative learning, on the other hand, is often seen as the more exotic variant with emphasises on creativity, originality and risk taking (McGrath, 2001; Katila, 2002). It is often credited with the development of ground-breaking, radical innovations and technologies of which the firm has little previous experience in.

In terms of the recognition of entrepreneurial opportunities (see Hills, Lumpkin and Singh (1997), Lumpkin, Hills and Schrader (2004), Lumpkin and Lichtenstein (2005), Schwartz and Teach (2000), and Wakkee and van der Sijde (2010), for further analysis), the role of explorative learning once again dominates the existing literature. Exploitative learning is generally associated with business opportunities utilising low innovation and growth potential (Schildt et al., 2005). They are likely to confined firms to "true and tried" entrepreneurial options that are not necessarily spectacular but unlikely to fail. Explorative learning, on the other hand, enables entrepreneurs to develop first mover advantage, by rapidly opening up new market and gain market share before competitors entering the market. That said, although explorative learning is more able to create innovation, it tends to be less predictable. March (1991) states that: "Compared to returns from exploitation, returns from exploration are systematically less certain, more remote in time, and organizationally more distant 
from the locus of action and adaptation... The certainty, speed, proximity, and clarity of feedback ties exploitation to its consequences more quickly and more precisely than is the case with exploration" (p73). This suggests that balancing explorative and exploitative learning remain crucial for firm in developing a strong business foundation, as well as developing business ideas.

Understandably, most studies in the field focused on explorative learning in the knowledge-based, intangible assets dominated, rapid-changing and globalised sectors (Eisenhardt and Martin, 2000; Ambrosini et al., 2009). Our study switch the context from one that is munificent and dynamic to the historical context of war and conflict where the environment can be considered as penurious and unpredictable, and focus on exploitative rather than explorative learning. War and conflict undoubtedly fell within the high-velocity or dynamic markets category proposed by Zollo and Winter (1999) and Rindova and Kotha (2001). As with any other evolutionary conditions, radical and unpredictable changes such as blockade, change in war effort, price of goods and hyperinflation all create disequilibrium that prevents organisations from rationally and deliberately codifying these changed experiences (Zollo and Winter, 2002 and Thomas et al., 2001) and precisely specifying future events (Pandza and Thorpe, 2009). War and conflict can also cause random destruction on people, building, infrastructure, and transport links, with the capacity to make previous valuable resources redundant overnight (Coble, 2003). These unpredictable changes resulted in highly ambiguous industry structure with different players shifting in and out of the picture regularly. It has been suggested that under such extremely volatile condition, developing dynamic capabilities is likely to become simple, experiential and fragile processes with unpredictable outcomes (Eisenhardt and Martin, 2000). 
Nevertheless, what set war and conflict apart from other forms of evolutionary environment is that boundary spanning activities are largely limited, due to restricted physical movement, cross-sectoral mobility, knowledge dissemination and network development opportunities. Under such environment, the ability to acquire additional resource is highly restricted. Such restriction may have serious consequences in the way that organisations develop and revise their resource and knowledge bases, and the way that new opportunity and innovation are developed.

Because of the different context, the learning process under such environment is likely to be different. This study examines the case of one family business in Hong Kong before, during and after the World War Two. We first examine the case in more details, before discussing how exploitative learning has been utilised to pursue and develop business opportunities. In the next section, we shall first discuss the methodology surrounding our case. The case is divided into four episodes. The four episodes which provide an outline of the context and of the businesses that the family engaged in, with the prologue focusing on the period before the war, the second episode on the first half of the occupation period, the third episode on the second part of the occupation when the general situation has worsen and, finally, the epilogue examining how the family fared when peace returned. We then examine how the finding is related to the existing literature on explorative and exploitative learning and concludes with managerial and policy implications.

\section{Research Methodology}


The study adopts a qualitative, longitudinal historical approach and examines a family businesses as Hong Kong is going into war from a long period of peace, and then from being occupied to the return of peace. Unlike previous work, however, this study relies extensively on oral history, which is the recording, preservation, interpretation and historical reconstruction of significant past events from an eye-witness's personal point of view (Grele, 1996). Although oral histories can be considered to be similar to other narratives, the uniqueness of these oral history materials lies with its extensive coverage of life events, providing the whole story rather than focusing on a particular episode (Thompson, 2000). Such longitudinal emphasis enables the research to cover longer epochs and biographic histories (Merlin, 1992; Sheeley, 2002; Umphrey, 2002) that is highly suitable to a change-orientated context such as war and conflict. Compared with other historical information, oral history enabled the study of individual testimonies that detailed the local, native and marginalised point of view that were often ignored by mainstream historical sources (Thompson, 2000; Portelli, 2006), which is particularly important for the context of war and conflict where records were completely destroyed or only very few were kept. Of course, the oral history approach shares the downside of other narrative analysis including validity, reliability, subjectivity (Webster and Mertova, 2007) and particularly the excessive reliance on memory (Welch, 2000). Nevertheless, oral historians have argued that, when carefully probed and scrutinized, memory can take us to unfamiliar places that challenge every convenient or self-serving claim about the past (Thompson, 2000). Oral historians have argued for the durability and organisation of memory, and that memory on dramatic events such as war and conflict tend to be more lasting (Thompson, 2000). In addition, oral narrative accounts, like all sources, should not be taken on faith but weighed alongside other accounts and evidence (Thompson, 2000). 
In order to increase its reliability, triangulation will be conducted with institutional records in universities and national archives as well as expert verification to create an equal dialogue between the historians' awareness of the broad spatial and temporal patterns, and the local narrator's closely focused personal narratives (Portelli, 2006).

The case is based largely on 50 hours of interviews with the key informants over two 3 -month periods. We relied on a number of informants from the $2^{\text {nd }}$ and $3^{\text {rd }}$ generations of the family business. These interviews initially followed a chronological order before moving onto specific themes, including boat customs and discrimination. These discussions were often facilitated by the presentation of old family photos. The aim of the interviews is to focus on their personal experience, rather than their subjective opinions of issues that they did not experience first-hand. Other information unrelated to the family business, such as family dynamics and personal interests, were also included in the interviews. These interviewees nevertheless provide some good sources of information regarding the personality of the informant as well as the context of which they and their family business was based; many oral historians argued that these are extremely important to the decision making processes elsewhere (Welsh, 2000). Repeated interviews were conducted and interviewees were asked to return to previously provided information for further elaboration.

\section{Prologue and the research context}

The Yip family came from a nomadic fisherfolks background living on junks and fishing crafts. The family was based in the bustling Victoria Harbour close to the central business district and various warehouses on both sides of the harbour. Before 
the full scale Japanese invasion of China, the family were already operating a ship-toshore transportation business carrying goods between open seas freighters anchored in the middle of the harbour and warehouses ashore. The family specialised in the delivery of coal, charcoal and high quality Singaporean firewood for industrial uses on a large scale, and possessed their own wooden trading coaster and sampans. Master Yip normally dealt directly with warehouse owners, managers, and middlemen who acted on behalf of the government or mostly large British corporations. His daughter described that Master Yip was "fairly well-known within the harbour and was extremely well-connected". The nucleus of the Yip family consisted of the master, his two wives, the elder daughter, and three younger sons.

However, despite their status in the harbour, they, like many other fisherfolks at the time, felt marginalised by the mainstream society. Ward (1965) described the boat people as "dragons on water, worms on shore", as most of them were born, married and died on their boats, with restricted interaction with landsmen as a result of centuries of stigmatisation, marginalisation and humiliation (Anderson, 1972; Ward 1985; Chan, 2000). Discrimination was a topic that was mentioned by members from the family, with some provided extensive accounts of these experiences, their fear of being discriminated, and general difficulties to integrate into the mainstream society. The lack of interaction discouraged the dissemination of outside sources of knowledge and competence (Nonaka, 1994), which held back their development for few centuries. Interesting, it was the same isolation that allowed the boat families in this study to develop their unique advantage during the war, and effectively prohibited landsmen to share their fortune at a time of general hardship. Decades of close interaction amongst a small and isolated group helped them to develop trust and 
repeated interaction with each others. In addition, common context helped to develop routines, practices and terminologies and enhanced the flow of knowledge through alliance and aid interpretation (Rosenkopf and Almeida, 2003) amongst boat people. Nevertheless, such closeness may restrict knowledge acquisition as they may merely duplicate pre-existing capabilities.

\section{Early part of the Japanese occupation in Hong Kong}

In December 1941 Japan captured Hong Kong and occupied the territory for three years and eight months. The strategic importance of Hong Kong as a transhipment centre for the proposed co-prosperity sphere meant that it was treated differently from other Japanese colonies (Lau, 2009, p.2) and other foreign concessions in China that were returned to the Japanese-supported Chinese collaborationist government (Lethbridge, 1969, p.97). Instead Hong Kong was put under the direct control of the Imperial Armed Force, who governed Hong Kong with a highly-centralised, militarydriven management approach (Lethbridge, 1969, p.97; Chow, 2007, p.1). As Japan continued to intensify their warfare in other parts of Asia, trading with outside the sphere became impossible. Rations for rice, cooking oil, sugar, salt and other food and food-processing commodities began one month after the occupation (Tse, 1995, p.114). Likewise, fuels were classified as strategic military resources and the distribution of these resources were severely restricted and centralised (Tse, 1995, p124). Private trade and distribution of these resources were prohibited. Few households and corporations were entitled to the use of gas and electricity (Cheng, 2006), while rations were imposed on household fuels, such as charcoal, firewood and matches (Cheng, 2006). The Japanese authority took charge of most strategic 
enterprises including pubic utilities, public transport and certain heavy industrial plants (Snow, 2003, p.156), retained possession of most warehouses and goods within them (Snow, 2003, p.168-170), and craved-up small but strategic local businesses, such as light factories, either through direct buy-out or forced partnership with Japanese elites who resumed control of productions (Snow, 2003, p.157). Physical movements of human were severely restricted except for out-migration that alleviated general shortages. The authority imposed an all-night curfew on all non-Japanese nationals and set up numerous checkpoints across the territory.

Whilst many other families lost their production capacities owing to the destructions of physical investment, loss of manpower and confiscations of resources, as mentioned by numerous authors, the uneven destruction and redistribution of power of war often create enormous if somewhat uneven and arbitrary entrepreneurial opportunities (Gottschalk, 2009; Coble, 2003). The ill-fated businesses of many others were in sharp contrast with the fortune of the Yip family, which managed to maintain linear continuality. It is hard to explain why the Yip family were allowed to maintain continuity when many others were forced out of the harbour. However, a narrative from another entrepreneur revealed that the Japanese's preference of a centralised logistical network may have led to the selection of a small number of key operators and forced the smaller operators to coerce with their larger contingents. Such command-and-control strategy is understandable given that the overarching aim was to efficiently exploit Hong Kong's transhipment capacity. The choice of the Yip family therefore reflected their relative status in the harbour, their knowledge in the trade, their infrastructures, and their relatively well-developed network. Such unique pre-existing resource and knowledge bases are impossible for competitors or potential 
new entries to imitate. As a result of the war, these resources also became nonsubstitutable due to lack of transportation alternative and therefore highly valuable.

A $2^{\text {nd }}$ generation family member explained that working for the Japanese was essentially the same as working for the British, as they were both absence from the harbour and both relied on their middlemen who are Chinese. Their existing knowledge remain the foundation for their business. Nevertheless, they had to 'learn a few things' to adapt to the new order. In this episode these learning are exploitative and mostly about contextual issues. Most notably they had to learn to operate most efficiently within the new restricted trade hours due to curfew and restrictive movement beyond the harbour. This required some night operations to cease, and required them to move some of the operations, such as cleaning of the equipment, to their resident boat where they were required to stay during the night. In this episode, most of the learning required was for the adaption to the new environment and a new culture, which altered very little the core of their businesses but nevertheless essential for their survival. They therefore learn exploitatively by engaging in the process of incremental augmentation and then reassess for changes that they made.

\section{Continued struggle and the rise of new entrepreneurial opportunities}

Shortages of food and fuels were intensified by the last months of 1942, when Japan began to lose grounds on the Pacific front. The American navel blockade that aimed to prohibit Japanese reinforcement and re-supply efforts resulted in the sinking of roughly one merchant ship per day, and destroyed over million tons of shipments (Snow, 2003, p.167). Hong Kong's overseas trade was being strangulated. If anything, Japan became more determined to ensure the colony's meagre resources were 
reserved for military purpose. Food situation was desperate for civilians (Tse, 1995, p122-123; Tse, 1995, p.120; Cheng, 2006; Snow, 2003. p209) and rations for many food related commodities and their substitutes became irregular and eventually discontinued (Tse, 1995, p.120; Cheng, 2006; Snow, 2003. p209). Fuel situation was equally dire. By August 1944, coal stocks were exhausted (Snow, 2003, p206) and gas and electricity supplies were suspended (Cheng, 2006). Without fuel, public transports were grounded to a halt and only very few manufacturing production could continued. At household level, prices of rationed firewood went up by more than 8 times between 1942 and 1944, before the authority stopped providing it to the public altogether by October (Cheng, 2006). These excess demands rapidly turned Hong Kong into an anthill of hoarding, speculation and black marketeering (Snow, 2003, p.123). Despite outlawed, profit-seeking farmers from the outliers continued to bring their food production into the territory (Tse, 1995, p.117). Black market price for fuel also rocketed (Cheng, 2006). Enterprising individuals began to collect woods and leafs - practices that were often discouraged by the law enforcement (Snow, 2003). Some began to sell pieces of furniture taken from their homes, whilst workers from gas and electricity plants sold reused coal in the market. These were of course illegal behaviours and subjected to severe punishments if caught.

The Yip family became involved in the illegal fuel trade. Initially, the family collected the leftovers from their hauling activities, bagged them and resold them to other haulers within the harbour. Coal picking is a long-standing practice mutually understood by the hauler and those who requested the transportation as an alternative to tipping, however, as the trading of fuel became extremely profitable, the family began to systematically extract coals from their shipments. Employees would kick any 
dropped items to the invisible parts of the boats and into cracks between wooden planks on the flooring. When offloading coals from gunny bags they would hold onto two handfuls to take back to the boat. As profit grew, the family began to invest substantially in the diversification. They acquired more boats and also began to acquire other sources of coals including buying from coolies and other suppliers. In addition, the family also began to collaborate with outsiders. They set up strategic alliances with their extended family members with the agreement to share carriers and labourers. Joint venture between the Yip family and their extended family were also set up for the purpose of boat purchase.

Reconfiguration of labourer also occurred within the business empire. Master Yip continued to be the figurehead who drove forward this extended empire, and his extensive knowledge about the coal market and network within the harbour remained crucial to the development of the business. This includes not only the buyers and the sellers, but also the water police who were willing to turn a blind eye to their illegal operation, and tipped them off when Japanese inspectors arrived in the harbour. Other male members were involved in the running of boats and physical duties, while female and junior family members cleaned, maintained and repaired retail equipments. Family members who lived on the residential boats would also act as security guards during the low tide to prevent petty thefts of spare coals that were deposited into the sea attached to the residential boat by a rope. The fuel trading business went really well during the last days of war and the family lived a fairly comfortable existence in the harbour, contrasting sharply with the harsh environment faced by the general population. 
In this episode, despite the new business activity, the learning requires to move into the new business opportunity remain largely exploitative. They have moved into the new market of illegal fuel, which has very different rules and norms to the haulage market that they were involved in. However, the fact that the family have already possess skills in haulage and in handling fuel, as well as their knowledge of the local market forms the platform, makes the learning exploitative and incremental from their pre-existing skillsets. This enables them to pick up the new learning that other was unable to do so and springboard onto the new market of illegal fuel trade that was taking place within the harbour. As the learning was made possible through the internal configuration of the family business, the subsequent entrepreneurial opportunity that they discovered was difficult to imitate by the outsiders. It is also important to note that learning was largely localised with the family remained on the waterfront throughout the episode. The skills that they need to require was about the specific rules and norms of a particular sector which was highly localised.

Although the Yip family prospected throughout the period, and that taking up additional entrepreneurial (often illegal) activities was not uncommon, many others fisherfolks struggled far more. Pre-existing resource and knowledge bases appear to be particularly essential for exploitative learning that is essential for the successful exploitation of opportunity recognition. For the Yip family, the possession of physical assets, the extensive network connection within the harbour, and the green light given by the Japanese enabled the family to immediately recognise the new opportunities and make incremental reconfiguration to their resources base in order to utilise the new opportunity. Others without such strong resource base had to look for alternative opportunities that are less profitable. Many had to leave their boats and went on shore, 
some even away from the territory. In the case of the Yip family, opportunity recognition depended largely on the successful exploitation of local knowledge and resources base. Similarly, the family families sought finance and collaboration from friends and family at a time when external resources acquisition would otherwise be impossible.

Explorative learning, on the other hand, was seen as highly difficult to achieve during the war. The uncertainties associated with resources availability, demand and supply are largely uncertain, making risk taking a very dangerous task, as there is little an entrepreneurial firm who wasted their effort and resources on failed learning can fall back on.

\section{Post War Epilogue}

When Japan surrendered in August 1945, freight and other transhipment businesses resumed. The Yip family returned to haulage when the demand for illegal coal plummeted after the war. However, during the war the family acquired considerable physical resources for the fuel trading activity, and the excess capacity now resulted in high running costs. Nevertheless, business reconfiguration and internal merger for cost reduction was considered as socially undesirable as they would affect the family dynamics between siblings. Due to the low demand of fuel transportation, most of the family members diversified into other food and products. However, as their boats got older, the siblings ran into a vicious circle of boat deterioration, lower demand due to worsening boat appearance, lower revenue, lower investment in maintenance, and further boat deterioration. Eventually, many of the off-shoots, such as those operated 
by the $2^{\text {nd }}$ generation family members, had to close down their branches of the business in the late 1940s and early 1950s. Without a boat dwelling of a good condition, all three left their fisherfolk lifestyle behind and went on shore to search for employment opportunities. Master Yip's status within the harbour faded and when Master Yip passed away in the 1960s, his only carrier was succeeded by his youngest son, who continues the family business until this day. Containerisation further diminished their profit and with the family now based on shore and his sons finding employment, the family business is unlike to sustain beyond the current generation.

\section{Discussion}

Although empirical work examining the two aspects of learning (explorative and exploitative) is now extensive, work concerning the successful development of exploitative learning in the face of war and conflict is still very limited. Through a detailed comparative examination of the history of a family business in the backwater of Hong Kong for a period of over half a century, this qualitative, exploratory research contributes to a clearer understanding of the nature of explorative learning both at times of war and peace. Our findings point to the different roles of exploitative and explorative learning at different types of evolutionary environments. We found that, at times of war and conflict, firms are limited both geographically and technologically in their search for new knowledge. The harsh reality of life made explorative learning and the radical search of opportunity discussed in Baron (2006), Ardichvili et al. (2003) and Rosenkoft and Nerkar (2001) a far less desirable option, as the forgone income can be critical to survival. Under such condition, most entrepreneurial organisations are stimulated to exploit their existing knowledge 
competencies to learn to become involved in new entrepreneurial opportunities. This is consistent with Bhave (1994), who found that firms are restricted from engaging in risky radical explorative behaviour in such a context. Consequently, we found that the ability of an organisation to exploit local resources and knowledge that are unique, non-replicable and coveted becomes crucial. In other words, being at the right place at the right time largely determines the success of war businesses.

On the other hand, at the time of peace, whether to engage in local exploitative or radical explorative learning becomes a matter of organisational choice. Consistent with previous research, our exploratory finding suggests that, under this type of evolutionary environment, it is the willingness to engage only in exploitative learning, and the refusal to engage in radical external explorative learning that is most likely to lead to low organisational performance. In essence, the family took a logical incremental approach involving mainly exploitative learning, and was left behind by the rapid development of post-war Hong Kong. They adapted essentially the same approach as they had used during the war, which was to springboard onto new opportunities through existing capacities and a bit of localised exploitative learning. This approach means that they were unable to acquire new knowledge and competencies that may be useful for them to look beyond the harbour. Whilst the harbour had been their fertile playground in the past, it became much less fruitful after the war due to the return of other forms of transportation. Local exploitative learning thus became less productive, and the limitations of local network and alliances with firms of similar background became apparent. Whilst a number of fisherfolks went on land to search for further opportunities, they family was reluctant to do so not due to lack of financial strength, but due to the uncertainties associated with such move. In 
other words, it was their reluctance to learn exploratively confined them to a life in the harbour.

In addition, successes of exploitative learning during the war as well as the absence of entrepreneurial spirit appeared to have trapped the family within their preexisting core competencies, and resulted in their unwillingness to explore new opportunities elsewhere as suggested by Sorenson and Stuart (2000). When asked, a $2^{\text {nd }}$ generation family member felt that moving ashore would expose them to the uncertainties that lie ahead, whilst the harbour is where they were born and brought up and they had everything they wanted there. Ironically, it was precisely such core rigidity that ultimately forced them to abandon their boat lifestyle. The family became dangerously exposed to external demand fluctuation, and when exogenous changes made their core competencies obsolete, they had no choice but to leave the livelihood that were so familiar to them behind. Therefore, just as few businesses made successful transformation from land to water during the time of war, few made it the opposite direction at the time of peace. Nevertheless, such transformation was by no means impossible, as illustrated by the parallel story of Henry Fok, a prominent entrepreneurs of fisherfolk background, whose life is well-documented.

\section{Conclusion}

The findings of this paper contribute to the understanding of business growth and development, both at times of war and conflict and the subsequent peace era. Although some studies have looked at the way entrepreneurship contributed to the post-conflict economies, however, due to data limitation, very few examined the 
nature of entrepreneurship at times of war and conflict, and, for the same reason, from a longitudinal perspective. Utilising a qualitative approach through a unique combination of historical archive, autobiography and interviews, our study managed to examine a family businesses - before, during and after war and conflict. Despite embedded in the past, we argue that our findings offer a number of managerial and policy implications.

In terms of managerial implication, we believe that exploitative learning offer entrepreneurial firms a chance to survive through the difficulties associated with the war and conflict environment. It is very important for entrepreneurial firms not to be disheartened by such environment, but instead, utilising their resource and competencies as the basis of their exploitative learning, which enables them to pursue further opportunities leading to better life prospects.

In terms of policy implication, we believe that knowing how wartime entrepreneurial businesses behaved both at times of conflict and peace can help revealing the type of entrepreneurs who are most likely to make the successful transformation, thus providing further understanding of how entrepreneurship can contribute to the reconstruction of post-conflict economy, as well as the types of support that policy makers can provide in lubricating the transformation process for these entrepreneurs. A question for policy maker could be whether they could offer any support to facilitate the transformation of wartime enterprises in a post-conflict environment. Our exploratory study found that success at the time of conflict created core rigidity (Leonard-Barton, 1992) and competencies trap, being consistent with previous finding such as Dunning and Lundan (2010) and Sorenson and Stuart (2000). In our case, 
such rigidness appears to be attributed to irreversible reconfigurations as well as lack of long term vision beyond their existing activities, as suggested by Schreyogg and Kliesch-Eberl (2007). Whilst the Schumpeterian (1942) or classical evolutionary economics' point of view suggested that such creative destruction is neither unusual nor unhealthy, however, in the particular context of war and conflict, the skills, knowledge and resources accumulated by the Yip family can contribute greatly to post-war economic recovery. Therefore there is perhaps a role for the likes of Master Yip to be at the forefront of the recovery process. As problems with entrepreneurial businesses lies with their lack of adventurism and core rigidity, policy makers can help them to overcome challenges and prepare them for change, such as through financial incentives or educational supports. Experiences of post-war South Korea in the 1950s suggested that such winner-picking behaviour by the government resulted in the efficient utilisation of pre-existing resources, and enabled these "chaebols" to compete in a global environment.

While this work takes an important first step towards understanding the processes of exploitation learning at the time of war and conflict, this study has a number of limitations. First of all, it is important to bear in mind that entrepreneurship is embedded in the context that it is based. Each war and conflict situation is unique in itself and therefore further study with relation to the subject is required before a convincing conclusion can be obtained. Second, we focus on the livelihood of one entrepreneurial family as the in-depth longitudinal approach requires considerable effort. However, the family may or may not be representative of an average case entrepreneurial family. In fact, may families would have flee the conflict zone altogether. Further studies including entrepreneurial families of different nature will 
be needed. Finally, further research, perhaps utilising a quantitative approach, is essential in understanding the entrepreneurship qualities required for both surviving the war as well as being able to make a successful transformation when peace returns.

\section{References}

Almeida, Paul and Kogut Bruce (1999) Localization of Knowledge and the Mobility of Engineers in Regional Networks, MANAGEMENT SCIENCE, Vol. 45, No. 7, July 1999, pp. 905-917

Ambrosini, V., Bowman, C. \& Collier, N. 2009. Dynamic capabilities: An exploration on how firms renew their resource base. British Journal of Management, 20: S9-S24. Ardichvili, A., R. Cardozo, et al. (2003). "A theory of entrepreneurial opportunity identification and development." Journal of Business Venturing 18(1): 105. Auh, S., and B. Menguc. 2005. Balancing Exploration and Exploitation: The Moderating Role of Competitive Intensity. Journal of Business Research, 58 (12): 1652-1661.

Bessant,J. , Caffyn,S. , High involvement innovation, International Journal of Technology Management, 1997, Vol:14, Pages:7-28

Boisot, M. \& Child, J. 1999. Organizations as adaptive systems in complex environments: The case of China. Organization Science, 10: 237-252.

Caloghirou, Y., Ioannides S, and Vonortas NS (2004). Research joint ventures: a survey in theoretical literature, in Y. Caloghirou, NS Vonortas and S. Ioannides (eds), European Collaboration in Research and Development: Business Strategies and Public Policies, Edward Elgar: Cheltenham, UK.

Cohen, W. and Levinthal, D. (1990) Absorptive capacity - A new persecive on learning and innovative, Administrative Science Quarterly, 35, 128-152.

Eisenhardt, Kathleen M. \& Martin, Jeffrey A. (2000). Dynamic capabilities: What are they? The Strategic Management Journal, 21(10-11): 1105-1121

Gibson, C. B. \& Birkinshaw, J. 2004. The antecedents, consequences and mediating role of organizational ambidexterity. Academy of Management Journal, 47(2): 209226.

Gottschalk, Petter (2009) Entrepreneurship and organised crime: entrepreneurs in illegal business. Edward Elgar Publishing, New York.

Grele, R (1996) Oral History: Method and Theory, Radical History Review 65:131135

Hills, G.E., Lumpkin, G.T. and Singh, R.P., 1997. Opportunity recognition:

Perceptions and behaviors of entrepreneurs. Frontiers of entrepreneurship research, 17, pp.168-182.

Helfat, C. 1994. Evolutionary trajectories in petroleum firm R\&R. Management Science. 40:1720-1747

Hamel, G., Doz, Y. L., \& Prahalad, C. K. (1989). Collaborate with your competitors and win. Harvard Business Review, 67(1), 133-139. 37

Jaffe, A., Trajtenberg, M., and Henderson, R. (1993) Geographic localization of knowledge spillover as evidenced by patent citations, Quarterly Journal of Economics, 108(3), 577-598.

Katila, R. (2002). New product search overtime: Past ideas in their prime? Academy 
of Management Journal, 45(5), 995-1010.

Kim, L. (1999) Building technological capability for industrialisation: analytical framework and Korea's experience, Industrial and Corporate Change, 8, 1, 111-136. Kogut, B. and Zander, U. (1992) Knowledge of the firm, combinative capabilities and the replication of technology, Organisation Science, 3, 383-397.

Leonard-Barton, D. 1992. Core capabilities and core rigidities: A paradox in managing new product development. Strategic Management Journal, 13: 111-125. Levitt, Barbara and March, James (1988) Organizational Learning, Annual Review of Sociology, Vol. 14: 319-338

Lumsden, C.J. (1999). Evolving creative minds: Stories and mechanisms . In R. J. Sternberg (Ed.), Handbook of creativity, pp. 153-168.

Lumpkin, G.T. and Lichtenstein, B.B., 2005. The role of organizational learning in the opportunity - recognition process. Entrepreneurship theory and practice, 29(4), pp.451-472.

Lumpkin, G.T., Hills, G.E. and Schrader, R.C., 2004. Opportunity recognition. Entrepreneurship: The way ahead, pp.73-90.

Martin, Xavier; Mitchell, Will; Swaminathan, Anand (1998) Structural change, industrial location and competitiveness (1998). Cheltenham, UK: E. Elgar.

March, J.G. (1991). "Exploration and Exploitation in Organizational Learning". Organization Science 2(1): 71-87.

McGrath, R. G. (2001). Exploratory learning, innovative capacity, and managerial oversight. Academy of Management Journal, 44(1), 118-131.

Milliken, F. J. 1987. Three types of perceived uncertainty about the environment:

State, effect, and response uncertainty. Academy of Management Review, 12: 133143.

Nagarajan Anuradha and Mitchell Will (1998) Evolutionary diffusion: internal and external methods used to acquire encompassing, complementary, and incremental technological changes in the lithotripsy industry, Strategic Management Journal, Volume 19, Issue 11, pages 1063-1077.

Nonaka, I. (1994).“A Dynamic Theory of Organizational Knowledge Creation,” Organization Science 5:1, 14-37.

Nonaka, Ikujiro; Takeuchi, Hirotaka (1995). The knowledge creating company: how Japanese companies create the dynamics of innovation. New York: Oxford University Press.

PANDZA, K., THORPE, R. (2009). Creative search and strategic sense-making:

Missing dimensions in the concept of dynamic capabilities. British Journal of

Management. vol. 20, no. 1S, pp. S118-S113.

Porter Michael (1990) - Competitive advantages of nations. Free Press: New York.

Portelli, A. (2006) Foreword. In A. Lanman. \& S. Wendling (Eds.) (2006). Preparing the Next Generation of Oral Historians: An Anthology of Oral History Education.

U.S.A: AltaMira Press, p. xiv -xv. 38

Raisch, Sebastian; Birkinshaw, Julian; Probst, Gilbert; Tushman, Michael L. (2009)

Organizational Ambidexterity: Balancing Exploitation and Exploration for Sustained Performance, ORGANIZATION SCIENCE, Vol. 20, No. 4, July-August 2009, pp. 685-695

Powell, Walter W., Kenneth Koput, and Laurel Smith-Doerr. (1996)

"Interorganizational Collaboration and the Locus of Innovation: Networks of Learning in Biotechnology.” Administrative Science Quarterly 41 (1): 116-45. Rosenkopf, L. and P. Almeida. (2003) "Overcoming Local Search through Alliances and Mobility." Management Science, 49:751-766. 
Rosenkopf, L. and A. Nerkar. "Beyond Local Search: Boundary-spanning, Exploration, and Impact in the Optical Disc Industry." 2001. Strategic Management Journal, 22: 287-306.

Ronstadt, R. (1988). The corridor principle. Journal of Business Venturing, 3(1), 31 40 .

Schildt, H. A., Maula, M. V., \& Keil, T. (2005). Explorative and exploitative learning from external corporate ventures. Entrepreneurship Theory and Practice, 29(4), 493515.

Schwartz, R.G. and Teach, R.D., 2000. Research note: entrepreneurship research: an empirical perspective. Entrepreneurship: Theory and Practice, 24(3), pp.77-77.

Shane, S. (1999) 'Prior Knowledge and the Discovery of Entrepreneurial Opportunities', Organization Science 11: 448-69.

Sorensen, Jesper B and Stuart, Toby E. (2000) Aging, obsolescence, and organizational innovation, Administrative Science Quarterly , 45(1), 81 - 112.

Stuart, T.E., \& Podolny, J.M. 1996. Local search and the evolution of technological capabilities . Strategic Management Journal, 17: 21-38

Teece, D. J. og Pisano, G. et al. (1997). ’Dynamic Capabilities and Strategic

Management". Strategic Management Journal, 18: 509-533

Thompson Paul (2000) The Voice of the Past. Oxford University Press: Oxford.

Tripsas, M. 1997. Unraveling the process of creative destruction: Complementary assets and incumbent survival in the typesetter industry. Strategic Management Journal, 18(Special Summer Issue): 119-142.

Tsoukas, H. and Knudsen, C. (2002). The Conduct of Strategy Research. In Pettigrew, A., Thomas, H og Whittington, R. (red.), Handbook of Strategy and Management. London: Sage

Tushman, Michael L., and Elaine Romanelli 1985 "Organizational evolution: A metamorphosis model of convergerce and reorientation." In L. L. Cummings and Barry M. Staw (eds.), Research in Organizational Behavior, 7: 171-222. Greenwich, CT: JAI Press.

UCBASARAN, D., ALSOS, G., WESTHEAD, P. \& WRIGHT, M. (2008) Habitual Entrepreneurs, Foundations and Trends in Entrepreneurship. 39

Webster, Leonard and Mertova, Patricie (2007) Using narrative inquiry as a research method. Routledge: New York.

Wakkee, I. and van der Sijde, P., 2010. ICT Opportunities Unlimited: The International Dimension in. E-Commerce Adoption and Small Business in the Global Marketplace: Tools for Optimization: Tools for Optimization, p.174.

Winter, S.G. (2000). The satisficing principle in capability learning, Strategic Management Journal, 21 (Special issue): 981-996

Zollo, M. and Winter, S.G. (2002). Deliberate learning and the evolution of dynamic capabilities, Organization Science, 13: 339-351 